\title{
Effects of the European hornet (Vespa crabro Linnaeus 1761) crude venom on its own species
}

Jerzy Nadolski

\begin{abstract}
Background: Lethal dose $50 \%$ is a classical index of toxicity that usually employs small rodents as experimental animals. Therefore, scarce data are available on the effects of venom on invertebrates, particularly the impact of wasp venom on its own species.

Findings: In the present study, the lethality of Vespa crabro venom on its own species was studied. Lethal dose $50 \%$ values of crude venom on workers of hornet Vespa crabro were estimated to be $4.0 \mathrm{mg} / \mathrm{kg}$ of body weight.

Conclusions: Wasps can use their venom apparatus effectively when attacking foreign workers that appear in the immediate vicinity of their nest. The toxins released during stinging are potent enough to kill. The result of this study eliminates the popular myth that venomous animals can be resistant to their own venom.
\end{abstract}

Keywords: European hornet, Vespa crabro, Hornet venoms, LD 50

\section{Findings}

The classical method of determining the toxicity of a substance is the lethal dose $50 \%\left(\mathrm{LD}_{50}\right)$, which is often used in analysis of different animal toxins [1-6]. Almost all studies about venom activity are based on the lethality of small rodents including mice and rats. There is little published data on the effects of venom on invertebrates [7]. Only a few studies on the lethal activity of a venom on its own species demonstrated significant results [8]. In addition, the degree of toxicity of venoms on individuals of their own species is unknown.

In the present study the toxicity of the European hornet Vespa crabro (Linnaeus, 1758) venom in relation to workers of its own species was assessed. Based on the author's own personal observations, it can be stated that hornets also sting to defend their nest against intruders of their own species, but from alien colonies. Thus, this study attempted, for the first time, to answer the following questions: did natural selection create defense mechanisms to protect these insects against their own toxins and how hornets are sensitive to their own venom?

The analysis of the toxic activity of Vespa crabro venom was carried out on workers from two colonies of hornets established in Łódź city in Central Poland.

Correspondence: nadolski@biol.uni.lodz.pl

Faculty of Biology and Environmental Protection, Natural History Museum, University of Łódź, Kilińskiego 101, 90-011, Łódź, Poland
Hornet venom was obtained by irritating insects with tweezers on their torso and abdomen, resulting in stinging reaction. The secreted venom was collected on watch glasses [8]. Then, frozen dried venom was stored in the dark at $-20^{\circ} \mathrm{C}$ until used. In order to obtain percent values of dry matter from liquid venom, specified quantities of venom were weighed [6]. The final venom concentration was adjusted with PBS (137 mM $\mathrm{NaCl}, 10 \mathrm{mM}$ phosphate, $2.7 \mathrm{mM} \mathrm{KCl}, \mathrm{pH}$ 7.4) [7].

After weighing, each hornet worker received, into the abdomen, the appropriate amount of venom by using a $1 \mu \mathrm{L}$ Hamilton microsyringe (USA). $\mathrm{LD}_{50}$ values for hornet workers (twenty workers per dose) at 24 hours were determined by the standard statistic method based on probit analysis [9-14]. Controls consisted o hornets injected only with PBS.

Table 1 displays the toxicity of Vespa crabro venom assessed on representatives of its own species. The obtained results underwent statistical analysis, including probit transformation, and the final value of $L D_{50}$ is presented in Table 2.

The $\mathrm{LD}_{50}$ of several aculeate venoms has been determined, including toxins of different hornet species, ranging from $1.6 \mathrm{mg} / \mathrm{kg}$ for Vespa luctuosa Saussure venom, $2.8 \mathrm{mg} / \mathrm{kg}$ for Vespa tropica L., $3.1-3.8 \mathrm{mg} / \mathrm{kg}$ for Vespa simillima Smith, 4.1-6.1 mg/kg for Vespa mandarinia Smith venom, to $8.7-10.9 \mathrm{mg} / \mathrm{kg}$ for the 
Table 1 Analysis of probit-transformed mortality of European hornet Vespa crabro workers provoked by their own venom

\begin{tabular}{|c|c|c|c|c|c|c|c|}
\hline $\begin{array}{c}\text { Dose ( } \mathrm{mg} / \mathrm{kg} \text { of body } \\
\text { weight) }\end{array}$ & $\begin{array}{l}\text { Log } \\
\text { dose }\end{array}$ & $\begin{array}{c}\text { Actual } \\
\text { mortality (\%) }\end{array}$ & $\begin{array}{l}\text { Probit-transformed actual } \\
\text { mortality }\end{array}$ & $\begin{array}{c}\text { Expected } \\
\text { probit }\end{array}$ & $\begin{array}{c}\text { Expected } \\
\text { mortality (\%) }\end{array}$ & $\begin{array}{c}\text { Chi-squared } \\
\text { statistic }\end{array}$ & $\begin{array}{c}\text { Degrees of } \\
\text { freedom }\end{array}$ \\
\hline 10 & 1 & 90 & 6.28 & 6.00 & 80 & 2.71 & 8 \\
\hline 9 & 0.95 & 75 & 5.67 & 5.88 & 81 & & \\
\hline 8 & 0.90 & 70 & 5.52 & 5.75 & 77 & & \\
\hline 7 & 0.85 & 75 & 5.67 & 5.63 & 74 & & \\
\hline 6 & 0.78 & 60 & 5.25 & 5.45 & 67 & & \\
\hline 5 & 0.70 & 50 & 5.00 & 5.25 & 60 & & \\
\hline 4 & 0.60 & 55 & 5.13 & 5.01 & 50 & & \\
\hline 3 & 0.48 & 40 & 4.75 & 4.71 & 39 & & \\
\hline 2 & 0.30 & 25 & 4.33 & 4.26 & 23 & & \\
\hline 1.5 & 0.18 & 20 & 4.16 & 3.96 & 15 & & \\
\hline
\end{tabular}

Chi-squared test was not significant.

venom of Vespa crabro [5,8]. However, all these values refer only to the mortality on experimental rodents, especially mice and rats. As shown by a previous study carried out on Calliphora sp. larvae, the toxicity of Vespa crabro venom is increased on these insects when compared to vertebrates, and is approximately about 2.7-7.6 $\mathrm{mg} / \mathrm{kg}$ [8]. Thus, these results support the hypothesis of greater toxicity of hornet venom on its potential prey (other insects), than on mammal aggressors. Other hymenopterans have more potent venoms, such as the solitary wasp Bracon hebetor Say. Its $\mathrm{LD}_{50}$ on lepidopterous larvae was found to be less than $0.3 \mathrm{mg} / \mathrm{kg}$ [15].

Venoms of arthropods, including insects, comprise a source of numerous bioactive compounds, which evolved for prey capture and defense against predators and microorganisms. The antimicrobial, insecticidal, and hemolytic properties of peptides isolated from arthropod venoms are well known, especially concerning arachnids (scorpions and spiders) and hymenopterans (ants, wasps and bees) [15-19]. Many of these peptides have been purified and their amino acid sequences have already been characterized.

The composition and properties of the several aculeate venoms, including those of wasps and hornets, have been extensively studied [4-6,20-25]. On mammals, vespid venoms provoke prolonged pain, local edema and erythema due to increased permeability of blood vessels

Table 2 Estimated $95 \%$ confidence interval for the $\mathbf{L D}_{\mathbf{5 0}}$ of hornet's workers Vespa crabro L. and standard error (SE) of LD $_{50}$

\begin{tabular}{ccc}
\hline Species & LD $_{\mathbf{5 0}}(\mathbf{m g} / \mathbf{k g})$ & SE of \\
& $\mathbf{2 4} \mathbf{h}(\mathbf{9 5} \% \mathbf{C l})$ & LD $_{\mathbf{5 0}}$ \\
\hline Vespa crabro workers & $4.0 \mathrm{mg} / \mathrm{kg}$ & 0.39 \\
\hline
\end{tabular}

in the skin. Besides these direct outcomes of hornet stings, allergic reactions have also been observed in numerous cases. The generalized allergic reaction may be lethal.

In addition to their systemic effects, wasp and hornet venoms act kinetically on isolated smooth muscle and reduce blood pressure. They release endogenous histamines from granulocytes including mast cells and basophilic leucocytes; and also release catecholamines from adrenal chromaffin cells. Such toxins may also provoke cytolysis, including hemolysis and chemotaxis to macrophages and polymorphonuclear leukocytes.

The overall action of wasp and hornet venoms is complicated and may be described as an accumulation of active principles of venoms. Compounds of several wasp venoms, including venom toxins from social wasps and hornets, have been isolated and investigated. Such venoms consist of complex mixtures of active amines (serotonin, histamine, tyramine, dopamine noradrenaline and adrenaline), peptides (pain-producing peptides such as kinins, and chemotactic peptides like mastoparan or crabrolin) and proteins including many types of hydrolases (i.e. proteases, hyaluronidases, phosphatases, nucleotidases and phospholipase A), as well as allergens and neurotoxins.

Many social insects have developed defensive systems that prevent infections within their colonies. For example, bee propolis and royal jelly present antimicrobial properties and the fecal pellets of termites inhibit the development of fungal pathogens [26,27]. Concerning ants, most species possess metapleural glands on the thorax whose secretions, spread over individuals and throughout the nest, have a broad spectrum of antimicrobial action. The antibacterial property of ant venom has been demonstrated, for example, in the fire ant, whose venom alkaloids inhibit bacterial growth and presumably act as an antibiotic [28]. Venoms of honey bees, wasps and 
hornets, including Vespa crabro, possess antimicrobial peptides; however, their natural functions must be further clarified $[26,29,30]$.

In addition to the development of social behavior, aculeate venom composition underwent evolution towards producing toxins that would be more effective against potential attackers. Usually solitary wasp venoms are employed primarily to paralyze and then kill prey [23]. Although Vespinae subfamily produces venoms that are efficient for hunting and self-defense, the most effective venom regarding defense is that of Apis mellifera $[8,22]$. Its main component is melittin, a powerful detergent that provokes hemolysis of red blood cells [30,31].

Aculeate venoms are used not only to attack prey, but also to defend the colony against foreign individuals [32]. Observations by the present author demonstrate the importance of hornet sting in nest defense against other colonies. Wasps use their venom apparatus effectively when attacking foreign workers that appear in the immediate vicinity of their nest. The toxins released in such cases are potent enough to kill $\left(\mathrm{LD}_{50}=4.0 \mathrm{mg} / \mathrm{kg}\right.$ of hornet body weight - Table 2). The determination of $\mathrm{LD}_{50}$ eliminates the popular myth that venomous animals can be resistant to their own venom.

The present results indicate that Vespa crabro venom is toxic for its own species as well as to other insects. Therefore, although both are predators, wasps and hornets as are natural allies against different pest insects and the effectiveness of their venom is proven by the relatively high values of $\mathrm{LD}_{50}$.

Potent venoms represent a source of new insecticidal compounds because they act selectively on their molecular targets. Such toxins affect the invertebrate nervous system and several insecticidal compounds that belong to the class of peptides or polyamine-like compounds have been purified and characterized from the venom of several hymenopterans. Numerous studies are focused on isolating and assessing the lethality of insecticidal toxins from wasps. Their venoms are expected to be used for manufacture of bioinsecticides with high selectivity for different groups of insects [29].

Animal venoms have been employed in the analysis of different physiopathological processes, and have also been involved in the design of new therapeutic drugs. Wasp toxins, due to their biological effects, may constitute potential sources of pharmacologically active compounds particularly for neuropharmacology [33]. Finally, it is worth noting that various components of venoms from wasps and bees can be used for human therapy. A classic example is the honeybee venom, which is widely employed in natural medicine (apitherapy).

\section{Competing interests}

The author declares that there are no competing interests.
Received: 19 November 2012 Accepted: 15 March 2013

Published: 18 March 2013

\section{References}

1. Bayram A, Yigit N, Danisman T, Corak I, Sancak Z, Ulasoglu D: Venomous spiders of Turkey (Araneae). J Applied Biol Sciences 2007, 1(3):33-36.

2. Carrijo LC, Andrich F, de Lima ME, Cordeiro MN, Richardson M, Figueiredo SG: Biological properties of the venom from the scorpionfish (Scorpaena plumieri) and purification of gelatinolytic protease. Toxicon 2005, 45(7):843-850.

3. Russell FE: Snake venom poisoning, Volume 562. Philadelphia: JB Lippincott Company; 1980.

4. Habermehl GG: Venomous animals and their toxins. Berlin-New York: Springer; 1981

5. Schmidt JO: Chemistry, pharmacology, and chemical ecology of ant venoms. In Venoms of the Hymenoptera: biochemical, pharmacological and behavioral aspects. Edited by Piek T. London: Academic; 1986:425-508.

6. Schmidt JO, Yamane S, Matsuura M, Starr CK: Hornet venoms: lethalities and lethal capacities. Toxicon 1986, 24(9):950-954.

7. Sak O, Ergin E, Uçkan F, Rivers DB, Aylin ER: Changes in the hemolymph total protein of Galleria mellonella (Lepidoptera: Pyralidae) after parasitism and envenomation by Pimpla turionellae (Hymenoptera: Ichneumonidae). Turk J Biol 2011, 45(4):425-432.

8. Nadolski J: Zróżnicowanie własności toksycznych jadu wybranych żądłówek społecznych (Hymenoptera, Aculeata). Acta Univ Lodz Folia zool 2000, 4:3-24.

9. Reed $\sqcup$, Muench HA: A simple method for the estimated fifty percent end points. Amer J Hyg 1938, 27:493-495.

10. Finney DJ: Probit analysis. 3rd edition. Cambridge University Press; 1971.

11. Doull J, Klaassen CD, Amdur MO: Casarett \& Doull's Toxicology: the basic science of poisons. 3rd edition. New York: Macmillan Publishing Company; 1986.

12. Meier J, Theakston RDG: Approximate $\mathrm{LD}_{50}$ determination of snake venoms using eight to ten experimental animals. Toxicon 1986, 24:395-401.

13. Seńczuk W: Toksykologia. Warszawa: PZWL, Wyd III; 1999.

14. Throne JE, Weaver DK, Baker JE: Probit analysis: assessing goodness-of-fit based on back transformation and residuals. J Economic Entomol 1995, 88(5):1513-1516.

15. Quistad GB, Nguyen Q, Bernasconi P, Leisy DJ: Purification and characterization of insecticidal toxins from venom glands of the parasitic wasp, Bracon hebetor. Insect Biochem Mol Biol 1994, 24(10):955-961.

16. Manzoli-Palma MF, Gobbi N, Palma MS: Insects as biological models to assay spider and scorpion venom toxicity. J Venom Anim Toxins ind Trop Dis 2003, 9(2):174-185.

17. Windley MJ, Herzig V, Dziemborowicz SA, Hardy MC, King GF, Nicholson GM: Spider-venom peptides as bioinsecticides. Toxins 2012, 4(3):191-227.

18. Orivel J, Redeker V, Le Caer JP, Krier F, Revol-Junelles AM, Longeon A, Chaffotte A, Dejean A, Rossier J: Ponericins, new antibacterial and insecticidal peptides from the venom of the ant Pachycondyla goeldii. J Biol Chem 2001, 276(21):17823-17829.

19. Ross DC, Crim JW, Brown MR, Herzog GA, Lea AO: Toxic and antifeeding actions of melittin in the corn earworm, heliothis zea (boddie): comparisons to bee venom and the insecticides chlorpyriphos and cyromazine. Toxicon 1987, 25(3):307-313.

20. Habermann E: Chemistry, pharmacology, and toxicology of bee, wasp and hornet venoms. In Venomous animals and their venoms: Biochemical, pharmacological and behavioral aspects. 3rd edition. Edited by Bücherl W, Buckley E. New York: Academic; 1971:61-93.

21. Nakajima T: Pharmacological biochemistry of vespid venoms. In Venoms of the Hymenoptera: Biochemical, pharmacological and behavioral aspects. Edited by Piek T. London: Academic; 1986:309-327.

22. O'Connor R, Henderson G, Nelson D, Parker R, Peck ML: The venom of the honey bee (Apis mellifera). In Animal Toxins. Edited by Russell FE, Saunders PR. Oxford: Pergamon Press; 1967:17-22.

23. Piek T, Spanjer W: Chemistry and pharmacology of solitary wasp venoms In Venoms of the Hymenoptera: Biochemical, pharmacological and behavioral aspects. Edited by Piek T. London: Academic; 1986:161-307.

24. Chen L, Chen W, Yang H, Lai R: A novel bioactive peptide from wasp venom. J Venom Res 2010, 1:43-47. 
25. Yang $H, X u X, M a ~ D$, Zhang K, Lai R: A phospholipase A1 platelet activator from the wasp venom of Vespa magnifica (Smith). Toxicon 2008, 51(2):289-296.

26. Anderson KE, Eckholm B, Mott BM, Sheehan TH, Hoffman GD: An emerging paradigm of colony health: microbial balance of the honey bee and hive (Apis mellifera). Insectes Sociaux 2011, 58(4):431-444.

27. Rosengaus RB, Guldin MR, Traniello JFA: Inhibitory effect of termite fecal pellets on fungal spore germination. J Chem Ecol 1998, 24(10):1697-1706.

28. Blum MS, Walker JR, Callahan PS, Novak AF: Chemical, insecticidal and antibiotic properties of fire ant venom. Science 1958, 128(3319):306-307.

29. Monteiro MC, Romao PR, Soares AM: Pharmacological perspectives of wasp venom. Protein Pept Lett 2009, 16(8):944-952.

30. Banks BEC, Shipolini RA: Chemistry and pharmacology of honey bee venom. In Venoms of the Hymenoptera: Biochemical, pharmacological and behavioral aspects. Edited by Piek T. London: Academic; 1986:329-416.

31. Nabil ZI, Hussein AA, Zalat SM, Rakha MK: Mechanism of action of honey bee (Apis mellifera L.) venom on different types of muscles. Hum Exp Toxicol 1998, 17(3):185-190

32. Dijkstra KDB, Rivera AC, Andrés JA: Repeated predation of Odonata by the hornet Vespa crabro (Hymenoptera: Vespidae). Inter J Odonatology 2001, 4(1):17-21.

33. Schwartz EF, Mourão CB, Moreira KG, Camargos TS, Mortari MR: Arthropod venoms: a vast arsenal of insecticidal neuropeptides. Pept Sc 2012, 98(4):385-405.

doi:10.1186/1678-9199-19-4

Cite this article as: Nadolski: Effects of the European hornet (Vespo crabro Linnaeus 1761) crude venom on its own species. Journal of Venomous Animals and Toxins including Tropical Diseases 2013 19:4.

\section{Submit your next manuscript to BioMed Central and take full advantage of:}

- Convenient online submission

- Thorough peer review

- No space constraints or color figure charges

- Immediate publication on acceptance

- Inclusion in PubMed, CAS, Scopus and Google Scholar

- Research which is freely available for redistribution

Submit your manuscript at www.biomedcentral.com/submit
() Biomed Central 